\title{
The effect of insulin on the heart
}

\author{
Part 2: Effects on function during and post myocardial \\ ischaemia
}

\author{
L.J. Klein, F.C. Visser
}

Insulin infusion has been advocated in the treatment of myocardial ischaemia and myocardial infarction. There is evidence from experimental animal studies for a protective effect of high-dose insulin administration in myocardial ischaemia and myocardial infarction. In some relatively small study populations a reduction in mortality was reported in those patients who received glucose-insulin-potassium (GIK) during myocardial infarction, which was confirmed in two meta-analyses. However, it has not been possible to reproduce these positive results in large randomised clinical trials. (Neth Heart J 2010;18:255-9.)

Keywords: Cardiomyopathy; Founder Effect; Mutation; Myosin-binding Protein C

$n$ this second part of the review of the cardiovascular effects of insulin, we focus on the potential protective effect of insulin in myocardial ischaemia and discuss the large clinical trials which have been performed with insulin administration in acute myocardial infarction.

Myocardial protection of insulin in (experimental) myocardial ischaemia

\section{In vitro studies}

In vitro studies applying ischaemia to rat, ${ }^{1-4}$ guinea pig $^{5}$ and rabbit hearts ${ }^{6-8}$ reported improvement in systolic $^{2-8}$ and diastolic function ${ }^{2,6-8}$ when insulin was added to the perfusate after reperfusion. Two studies reported the best protection by insulin when it was added shortly before reflow was es-

\section{L.J. Klein \\ F.C. Visser}

Department of Cardiology, VU Medical Centre, Amsterdam, the Netherlands

Correspondence to: L.J. Klein

Department of Cardiology, VU Medical Centre, PO Box 7057, 1007 MB Amsterdam, the Netherlands

E-mail: lucasklein@xs4all.nl tablished after experimental occlusion., ${ }^{1,8}$ Insulin led to (relative) preservation of high-energy phosphates in many studies, ${ }^{4-6,8}$ as well as to a reduction in ultrastructural damage of the myocytes caused by ischaemia and anoxia, ${ }^{6}$ but did not change the high-energy phosphate depletion caused by ischaemia in one study. ${ }^{2}$ Also, addition of insulin to the perfusate preserved glycolytic flux during ischaemia $^{2,6-8}$ and increased lactate production, indicating increased anaerobic metabolism of glucose. ${ }^{2,7,8}$ Mitochondrial function and glycogen storages were maintained. ${ }^{3,5}$ A number of the observed effects correlated to each other: the left ventricular end-diastolic pressure (LVEDP) correlated strongly and negatively with the preserved adenosine triphosphate (ATP) content, lactate production and glucose uptake, myocardial glucose-uptake correlated positively with lactate production and ATP content. ${ }^{8}$ In a study in which dog hearts were perfused with the aid of another dog, perfusion was interrupted for two hours after pretreatment with glucose-insulin-potassium (GIK). Systolic function was preserved and myocardial damage was less in pretreated dog hearts compared with dog hearts which were not pretreated with GIK, thus indicating a preservative effect of GIK. ${ }^{9}$

Finally, reduction of infarct size by insulin administration after coronary occlusion seemed to be dependent on time of administration: infarct size was reduced when insulin administration was started just before reperfusion (and continued for 15 or 120 minutes), but not if insulin administration was started ten minutes after reperfusion. ${ }^{1}$ This may indicate protection against myocardial injury caused by reperfusion.

\section{In vivo experimental studies}

Insulin preserved systolic and diastolic function during ischaemia, or hearts from insulin-treated animals showed better recovery of function after reperfusion, ${ }^{10-18}$ but others did not observe an effect of insulin on postischaemic function. ${ }^{19-21}$ Interestingly, one of the positive studies infused insulin intracoronarily at a rate of $4 \mathrm{U} / \mathrm{min}$ in mongrel dogs 
Table 1. Glucose-insulin-potassium (GIK) in myocardial infarction studies.

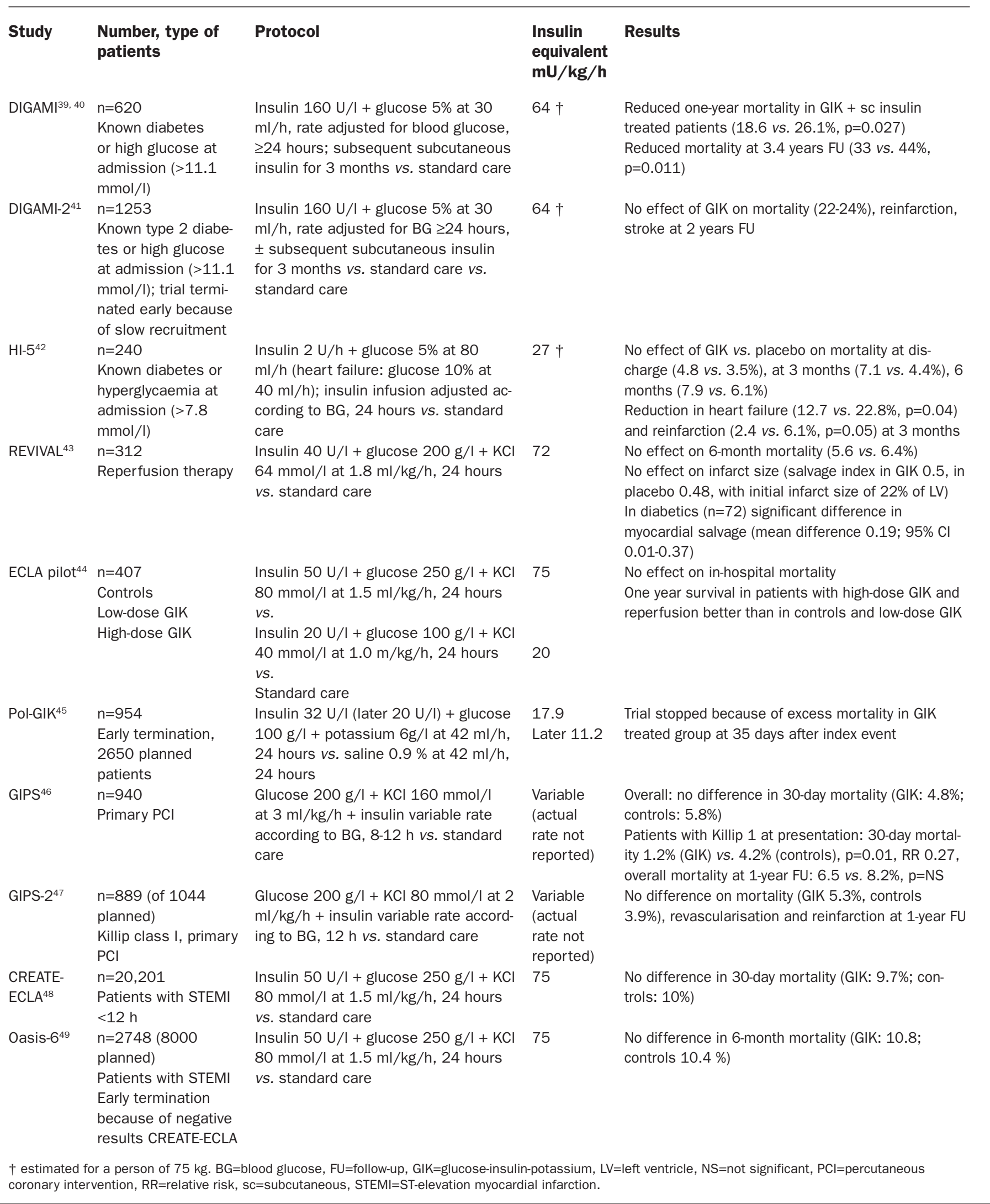


of 15 to $30 \mathrm{~kg}$ ( 130 to $260 \mathrm{mU} / \mathrm{kg} / \mathrm{min}$ ) without systemic effects. ${ }^{12}$ Intracoronary insulin infusion increased myocardial glucose uptake more than intravenous insulin but effects on function were not different from insulin administered intravenously (4 U/min, 130 to $260 \mathrm{mU} / \mathrm{kg} / \mathrm{min}$ ). ${ }^{12}$ The rate of insulin perfusion in this study was extraordinarily high compared with human studies (see below). Insulin administration during ischaemia relatively preserved high-energy phosphates, ${ }^{15,19,22-24}$ but showed no effect on high-energy phosphates in other studies. ${ }^{11,13}$ Histological and ultrastructural damage was limited in GIK administration during ischaemia compared with controls. ${ }^{19,25}$ Scar size and the amount of apoptosis were reduced, ${ }^{17,18,26}$ but in some studies scar size was not able to show an effect on scar or apoptosis. ${ }^{10,20}$ The area of necrosis was smaller if GIK was started during the induced ischaemia which was followed by reperfusion than when started at reperfusion; however, the reduction when started at reperfusion was still larger than in the control group. ${ }^{17}$

Conflicting results were also obtained with regard to the ST deviation, with a reduction of ST deviation during ischaemia and concurrent GIK administration ${ }^{10,21,22}$ but no difference was observed by others. ${ }^{11,24,27}$ Ventricular fibrillation occurred less frequently ${ }^{17}$ or as often as in controls. ${ }^{27}$

\section{Glucose-insulin-potassium in acute myocardial infarction}

In 1962, Sodi-Pallares et al. used potassium-glucose-insulin (so-called polarising solution) in ten patients with acute myocardial infarction and 20 patients with chronic coronary insufficiency. ${ }^{28}$ In three patients, the signs of acute ischaemia decreased, in two patients they worsened. In patients with chronic coronary insufficiency, alterations in repolarisation were observed as well. Ventricular arrhythmias almost disappeared and reoccurred when the infusion was stopped.

After the initial report by Sodi-Pallares, studies were performed applying GIK infusions, subcutaneous insulin in combination with glucose infusion or subcutaneous insulin and oral glucose and potassium as adjunctive therapy to myocardial infarction, a number of them with the aim to reduce in-hospital mortality. ${ }^{29-37}$ Fath-Ordoubadi and Beatt performed a meta-analysis of these studies, leaving out studies without a proper design. ${ }^{38}$ All these studies were performed in the prethrombolysis era. From the pooled data, a proportional mortality reduction of $28 \%$ (95\% CI 10 to $43 \%$ ) was calculated in favour of insulin administration in the setting of acute myocardial infarction. ${ }^{38}$ However, interpretation of the results of this meta-analysis is difficult, since the studies included in the meta-analysis have important methodological differences. Furthermore, the results can hardly be extrapolated to date, because the studies were mainly performed in the prereperfusion era.

After the publication of the meta-analysis by Fath-Ordoubadi and Beatt, ${ }^{38}$ a number of new studies have been published, which are summarised in table $1 . .^{39-49}$

In contrast to the meta-analysis of Fath-Ordouba$\mathrm{di}^{38}$ the conclusion from the overview in table $\mathrm{l}$ is that GIK administration does not reduce mortality in patients with acute myocardial infarction. There are only three studies with a true positive result: the DIGAMI study (patients with known diabetes or high glucose at admission), ${ }^{39,40}$ the pilot ECLA study (mainly in patients with reperfusion therapy by thrombolysis $)^{44}$ and the GIPS study for patients with Killip class $1 .{ }^{46}$ However, the DIGAMI-2, ${ }^{41}$ GIPS- $2,{ }^{47}$ the CREATE-ECLA trial ${ }^{48}$ and the OASIS-GIK ${ }^{49}$ did not show a reduction in mortality and are the largest trials on GIK in myocardial infarction ever performed.

The different regimens of insulin administration used in the trials are a point of concern. ${ }^{50}$ From data with experimental ischaemia in animals but also from those studies focusing on myocardial function in humans (see part 1 of this review), ${ }^{51}$ it is probably more important to give a high dose of insulin than to administer glucose and adjust insulin infusion rate. Furthermore, the applied dose of insulin in patients is generally much lower than in experimental animal studies.

In studies in patients with myocardial infarction not focusing on mortality, no effects were observed on oxidative stress ${ }^{52}$ or only a trend towards a larger amount of salvaged myocardium was observed..$^{53}$

\section{Summary and conclusion}

In experimental studies with myocardial ischaemia and myocardial infarction, glucose-insulin administration has a protective effect on myocardial function and reduces infarct size. The lack of effect in clinical studies (no effect on mortality in acute myocardial infarction) does not exclude a positive effect of high-dose insulin infusion on myocardial function.

\section{References}

1 Jonassen AK, Sack MN, Mjos OD, Yellon DM. Myocardial protection by insulin at reperfusion requires early administration and is mediated via Akt and p70s6 kinase cell-survival signaling. Circ Res. 2001;89:1191-8.

2 Weissler AM, Altschuld RA, Gibb LE, Pollack ME, Kruger FA. Effect of insulin on the performance and metabolism of the anoxic isolated perfused rat heart. Circ Res. 1973 January;32:108-16.

3 Doenst T, Richwine RT, Bray MS, Goodwin GW, Frazier OH, Taegtmeyer $\mathrm{H}$. Insulin improves functional and metabolic recovery of reperfused working rat heart. Ann Thorac Surg. 1999;67:1682-8

4 Angelos MG, Murray HN, Gorsline RT, Klawitter PF. Glucose, insulin and potassium (GIK) during reperfusion mediates improved myocardial bioenergetics. Resuscitation. 2002;55:329-36. 
5 Henry PD, Sobel BE, Braunwald E. Protection of hypoxic guinea pig hearts with glucose and insulin. Am J Physiol. $1974: 226: 309-13$.

6 Apstein CS, Gravino FN, Haudenschild CC. Determinants of a protective effect of glucose and insulin on the ischemic myocardium. Effects on contractile function, diastolic compliance, metabolism, and ultrastructure during ischemia and reperfusion. Circ Res. 1983;52:515-26.

7 Eberli FR, Weinberg EO, Grice WN, Horowitz GL, Apstein CS. Protective effect of increased glycolytic substrate against systolic and diastolic dysfunction and increased coronary resistance from prolonged global underperfusion and reperfusion in isolated rabbit hearts perfused with erythrocyte suspensions. Circ Res. 1991;68:466-81.

8 Vanoverschelde JL, Janier MF, Bakke JE, Marshall DR, Bergmann SR. Rate of glycolysis during ischemia determines extent of ischemic injury and functional recovery after reperfusion. Am J Physiol. 1994;267:H1785-H1794.

9 Krause BL, Wakefield JS, McMillan AB, Brown AH. Protection of the ischaemic myocardium by glucose-insulin-potassium infusion assessed by ventricular function and electron microscopy. J Cardiovasc Surg (Torino). 1978;19:421-32.

10 Ahmed SS, Lee CH, Oldewurtel HA, Regan TJ. Sustained effect of glucose-insulin-potassium on myocardial performance during regional ischemia. Role of free fatty acid and osmolality. J Clin Invest. 1978;61:1123-35

11 Heng MK, Norris RM, Peter T, Nisbet HD, Singh BN. The effect of glucose-insulin-potassium on experimental myocardial infarction in the dog. Cardiovasc Res. 1978;12:429-35.

12 Tune JD, Mallet RT, Downey HF. Insulin improves contractile function during moderate ischemia in canine left ventricle. Am J Physiol. 1998;274:H1574-H1581.

13 Tune JD, Mallet RT, Downey HF. Insulin improves cardiac contractile function and oxygen utilization efficiency during moderate ischemia without compromising myocardial energetics. J Mol Cell Cardiol. 1998;30:2025-35.

14 Zhu P, Lu L, Xu Y, Greyson C, Schwartz GG. Glucose-insulinpotassium preserves systolic and diastolic function in ischemia and reperfusion in pigs. Am J Physiol. 2000;278:H595-H603.

15 Cave AC, Ingwall JS, Friedrich J, Liao R, Saupe KW, Apstein CS, et al. ATP synthesis during low-flow ischemia: influence of increased glycolytic substrate. Circulation. 2000;101:2090-6.

16 Szabo Z, Arnqvist H, Hakanson E, Jorfeldt L, Svedjeholm R. Effects of high-dose glucose-insulin-potassium on myocardial metabolism after coronary surgery in patients with Type II diabetes. Clin Sci (Lond). 2001;101:37-43.

17 Lazar HL, Zhang X, Rivers S, Bernard S, Shemin RJ. Limiting ischemic myocardial damage using glucose-insulin-potassium solutions. Ann Thorac Surg. 1995;60:411-6.

18 Jonassen AK, Aasum E, Riemersma RA, Mjos OD, Larsen TS Glucose-insulin-potassium reduces infarct size when administered during reperfusion. Cardiovasc Drugs Ther. 2000;14:615-23

19 Maroko PR, Libby P, Sobel BE, Bloor CM, Sybers HD, Shell WE et al. Effect of glucose-insulin-potassium infusion on myocardial infarction following experimental coronary artery occlusion. Circulation. 1972;45:1160-75.

20 Bellows SD, Kloner RA. Glucose-Insulin-Potassium does not reduce myocardial infarct size in an ischemic/reperfusion rabbit model. J Thromb Thrombolysis. 1998;5:25-7.

21 Haneda T, Ganz W, Burnam MH, Katz J. Metabolic effects of glucose-insulin-potassium in the ischemic myocardium. Jpn Heart J. 1978;19:376-82

22 Calva E, Mújica A, Núñez R, Aoki K, Bisteni A, Sodi-Pallares D. Mitochondrial biochemical changes and glucose- $\mathrm{KCl}$-insulin solution in cardiac infarct. Am J Physiol. 1966;211:71-6.

23 Kambara H, Yoshida A, Kawashita K, Kawai C. Effects of glucose-insulin-potassium infusion on myocardial infarction and myocardial blood flow following experimental coronary artery occlusion. Jpn Circ J. 1981;45:1158-63.

24 Dalby AJ, Bricknell OL, Opie LH. Effect of glucose-insulinpotassium infusions on epicardial ECG changes and on myocardial metabolic changes after coronary artery ligation in dogs. Cardiovasc Res 1981;15:588-98.

25 Sybers HD, Maroko PR, Ashraf M, Libby P, Braunwald E. The effect of glucose-insulin-potassium on cardiac ultrastructure following acute experimental coronary occlusion. Am J Pathol. 1973;70:401-20.
26 Zhang HF, Fan Q, Qian XX, Lopez BL, Christopher TA, Ma $\mathrm{XL}$, et al. Role of insulin in the anti-apoptotic effect of glucoseinsulin-potassium in rabbits with acute myocardial ischemia and reperfusion. Apoptosis 2004;9:777-83

27 Opie LH, Bruyneel K, Owen P. Effects of glucose, insulin and potassium infusion on tissue metabolic changes within first hour of myocardial infarction in the baboon. Circulation. 1975;52:49-57.

28 Sodi-Pallares D, Testilli MR, Fishleder BL, Bisteni A, Medrano GA, Friedland C et al. Effects of an intravenous infusion of a potassium-glucose-insulin solution on the electrocardiographic signs of myocardial infarction. A preliminary report. Am J Cardiol. 1962;5:166-81.

29 Sievers J, Lindh J, Johansson BW, Karnell J. Acute myocardial infarction treated by glucose-insulin-potassium (GIK) infusion. Cardiology. 1966;49:239-47.

30 Mittra B. Potassium, glucose, and insulin in treatment of myocardial infarction. Lancet. 1965;286:607-9.

31 Pilcher J, Etismahudin M, Exon P, Moore J. Potassium, glucose, and insulin in myocardial infarction [letter]. Lancet. 1967;289:1109.

32 Medical Research Council working-party on the treatment of myocardial infarction. Potassium, glucose, and insulin treatment for acute myocardial infarction. Lancet. 1968;292:135560.

33 Pentecost BL, Mayne NM, Lamb P. Controlled trial of intravenous glucose, potassium, and insulin in acute myocardial infarction. Lancet. 1968;291:946-8.

34 Rogers WJ, Stanley AW, Jr., Breinig JB, Prather JW, McDaniel HG, Moraski RE, et al. Reduction of hospital mortality rate of acute myocardial infarction with glucose-insulin-potassium infusion. Am Heart J. 1976;92:441-54.

35 Heng MK, Norris RM, Singh BN, Barratt-Boyes C. Effects of glucose and glucose-insulin-potassium on haemodynamics and enzyme release after acute myocardial infarction. Br Heart J. 1977;39:748-57.

36 Rogers WJ, Segall PH, McDaniel HG, Mantle JA, Russell RO, Jr., Rackley CE. Prospective randomized trial of glucose-insulin-potassium in acute myocardial infarction. Effects on myocardial hemodynamics, substrates and rhythm. Am J Cardiol. 1979;43:801-9.

37 Satler LF, Green CE, Kent KM, Pallas RS, Pearle DL, Rackley CE. Metabolic support during coronary reperfusion. Am Heart J 1987;114:54-8.

38 Fath-Ordoubadi F, Beatt KJ. Glucose-insulin-potassium therapy for treatment of acute myocardial infarction: an overview of randomized placebo-controlled trials. Circulation. 1997;96:1152-6

39 Malmberg K, Ryden L, Efendic S, Herlitz J, Nicol P, Waldenstrom A, et al. Randomized trial of insulin-glucose infusion followed by subcutaneous insulin treatment in diabetic patients with acute myocardial infarction (DIGAMI study): effects on mortality at 1 year. J Am Coll Cardiol. 1995;26:57-65.

40 Malmberg K, Norhammar A, Wedel H, Ryden L. Glycometabolic state at admission: important risk marker of mortality in conventionally treated patients with diabetes mellitus and acute myocardial infarction: long-term results from the Diabetes and Insulin- Glucose Infusion in Acute Myocardial Infarction (DIGAMI) study. Circulation. 1999;99:2626-32.

41 Malmberg K, Ryden L, Wedel H, Birkeland K, Bootsma A, Dickstein $\mathrm{K}$, et al. Intense metabolic control by means of insulin in patients with diabetes mellitus and acute myocardial infarction (DIGAMI 2): effects on mortality and morbidity. Eur Heart J. 2005;26:650-61

42 Cheung NW, Wong VW, McLean M. The Hyperglycemia: Intensive Insulin Infusion in Infarction (HI-5) study: a randomized controlled trial of insulin infusion therapy for myocardial infarction. Diabetes Care. 2006;29:765-70.

43 Pache J, Kastrati A, Mehilli J, Bollwein H, Ndrepepa G, Schuhlen $\mathrm{H}$, et al. A randomized evaluation of the effects of glucose-insulin-potassium infusion on myocardial salvage in patients with acute myocardial infarction treated with reperfusion therapy. Am Heart J. 2004;148:e3.

44 Diaz R, Paolasso EA, Piegas LS, Tajer CD, Moreno MG, Corvalan $\mathrm{R}$, et al. Metabolic modulation of acute myocardial infarction. The ECLA (Estudios Cardiologicos Latinoamerica) Collaborative Group. Circulation. 1998;98:2227-34. 
45 Ceremuzynski L, Budaj A, Czepiel A, Burzykowski T, Achremczyk P, Smielak-Korombel W, et al. Low-dose glucose-insulinpotassium is ineffective in acute myocardial infarction: results of a randomized multicenter Pol-GIK trial. Cardiovasc Drugs Ther. 1999;13:191-200.

46 van der Horst IC, Zijlstra F, van 't Hof AW, Doggen CJ, de Boer MJ, Suryapranata H, et al. Glucose-insulin-potassium infusion inpatients treated with primary angioplasty for acute myocardial infarction: the glucose-insulin-potassium study: a randomized trial. J Am Coll Cardiol. 2003;42:784-91.

47 Rasoul S, Ottervanger JP, Timmer JR, Svilaas T, Henriques JP, Dambrink JH, et al. One year outcomes after glucose-insulinpotassium in ST elevation myocardial infarction. The Glucoseinsulin-potassium study II. Int J Cardiol. 2007;122:52-5.

48 Mehta SR, Yusuf S, Diaz R, Zhu J, Pais P, Xavier D, et al. Effect of glucose-insulin-potassium infusion on mortality in patients with acute ST-segment elevation myocardial infarction the CREATE-ECLA randomized controlled trial. JAMA. $2005 ; 293: 437-46$
49 Diaz R, Goyal A, Mehta SR, Afzal R, Xavier D, Pais P et al. Glucose-insulin-potassium therapy in patients with ST-segment elevation myocardial infarction. JAMA. 2007;28;298:2399-405.

50 Klein LJ, Visser FC. The effect of insulin on the heart. Part 1: Effects on metabolism and function. Neth Heart J 2010;18:255-9.

51 Cheung NW, Wong VW, McLean M. Insulin infusion therapy for myocardial infarction. Expert Opin Pharmacother. 2006; 7:2495-503

52 Diaz-Araya G, Nettle D, Castro P, Miranda F, Greig D, Campos $\mathrm{X}$, et al. Oxidative stress after reperfusion with primary coronary angioplasty: lack of effect of glucose-insulin-potassium infusion. Crit Care Med. 2002;30:417-21.

53 Castro PF, Larrain G, Baeza R, Corbalan R, Nazzal C, Greig DP, et al. Effects of glucose-insulin-potassium solution on myocardial salvage and left ventricular function after primary angioplasty. Crit Care Med. 2003;31:2152-5. 